\title{
CF750-A33scFv-Fc-Based Optical Imaging of Subcutaneous and Orthotopic Xenografts of GPA33-Positive Colorectal Cancer in Mice
}

\author{
Danfeng Wei, ${ }^{1}$ Qing Fan, ${ }^{1}$ Huawei Cai, ${ }^{2}$ Hao Yang, ${ }^{1}$ Lin Wan, ${ }^{1}$ Lin Li, ${ }^{2}$ and Xiaofeng Lu ${ }^{1}$ \\ ${ }^{1}$ Key Laboratory of Transplant Engineering and Immunology, Regenerative Medical Center, West China Hospital, Sichuan University, \\ Chengdu 610041, China \\ ${ }^{2}$ Department of Nuclear Medicine, West China Hospital, Sichuan University, Chengdu 610041, China
}

Correspondence should be addressed to Xiaofeng Lu; xiaofenglu@yahoo.com

Received 5 January 2015; Accepted 24 April 2015

Academic Editor: Dominic Fan

Copyright (C) 2015 Danfeng Wei et al. This is an open access article distributed under the Creative Commons Attribution License, which permits unrestricted use, distribution, and reproduction in any medium, provided the original work is properly cited.

\begin{abstract}
Antibody-based imaging agents are attractive as adjuvant diagnostic tools for solid tumors. GPA33 is highly expressed in most human colorectal cancers and has been verified as a diagnostic and therapeutic target. Here, we built an A33scFv-Fc antibody against GPA33 by fusing A33scFv to the Fc fragment of human IgG1 antibodies. The A33scFv-Fc specifically binds GPA33-positive colorectal cancer cells and tumor tissues. After the intravenous injection of mice bearing subcutaneous GPA33-positive LS174T tumor grafts with near-infrared fluorescence probe CF750-labeled A33scFv-Fc (CF750-A33scFv-Fc), high contrast images of the tumor grafts could be kinetically documented within $24 \mathrm{~h}$ using an optical imaging system. However, GPA33-negative SMMC7721 tumor grafts could not be visualized by injecting the same amount of CF750-A33scFv-Fc. Moreover, in subcutaneous LS174T tumorbearing mice, tissue scanning revealed that the CF750-A33scFv-Fc accumulated in the tumor grafts, other than the kidney and liver. In mice with orthotopic tumor transplantations, excrescent LS174T tumor tissues in the colon were successfully removed under guidance by CF750-A33scFv-Fc-based optical imaging. These results indicate that CF750-A33scFv-Fc can target GPA33, suggesting the potential of CF750-A33scFv-Fc as an imaging agent for the diagnosis of colorectal cancer.
\end{abstract}

\section{Introduction}

Colorectal cancer is one of the most common malignancies in the world, as the third most common cancer in men and the second in women [1]. Although colorectal cancer incidence rates are stabilizing or even declining in historically high-risk areas (United States, New Zealand, and Canada), they are rapidly increasing in several historically low-risk countries (China, Japan, Korea, and Eastern European countries) [2,3]. Colorectal cancer mainly results from a series of genetic changes leading to the progressive and irreversible loss of the normal control of cell growth and differentiation [4]. In addition, several environmental factors mostly related to diet and lifestyle have been identified and seem to play a certain role in the development of colorectal cancer [5].

The development of colorectal cancer has been revealed as an ordered process spanning three main phases: initiation, promotion, and progression [6]. Clinical data from colorectal cancer in high-resource countries have demonstrated that the mortality of colorectal cancer can be reduced by early treatment [7-9]. Consequently, early diagnosis plays important role in reducing the burden of colorectal cancer. However, the current diagnosis of colorectal cancer is limited by fecal occult blood tests (FOBTs), flexible sigmoidoscopy, and colonoscopy $[8,10]$. As a result, it is urgent to develop novel tools for the early diagnosis of colorectal cancer.

Noninvasive molecular imaging has become popular in recent years for the diagnosis of solid tumors [11, 12]. Antibodies against tumor cell-specific surface markers are ideal for tumor imaging because of their high specificity and affinity for antigens [13]. GPA33, a $43 \mathrm{kDa}$ membrane glycoprotein, is highly expressed in over $95 \%$ of human colorectal cancers [14]. In addition, no circulating GPA33 antigen has been detected [15]. These results suggest that GPA33 might be 
a candidate marker for the diagnosis and therapy of colorectal cancer. Consequently, many murine antibodies and their humanized antibodies against GPA33 have been developed in the past decades. Of these antibodies, A33 (a murine monoclonal antibody against GPA33) [16] and huA33 (the humanized A33) [17] have been widely used as imaging tools for mice with human colon cancer xenografts and for colon cancer patients $[16,18,19]$. However, these antibodies are limited by their low affinity for GPA33 [20].

It was well known that the affinity of rabbit antibodies is higher than that of murine antibodies. Consequently, a rabbit antibody against GPA33 has been developed and humanized [20]. As expected, the affinity of this humanized rabbit antibody against GPA33 (hurA33) was much higher than that of the murine antibody A33. A HurA33-derived single chain fragment of variable antibody $(\mathrm{A} 33 \mathrm{scFv})$ was recently developed for use in drug delivery [21, 22]. Considering the slow tumor targeting of large hurA33 and the low affinity of small $\mathrm{A} 33 \mathrm{scFv}$, it is better to develop divalent diabodies, minibodies, or scFv-Fc antibodies against GPA33 as imaging tools. In addition, taking into account the risk of radiation injury by radioactive antibodies, it is urgent to develop nonradioactive probes for antibody labeling. In fact, optical tumor imaging with near-infrared (NIR) fluorescence probelabeled antibodies has become more and more popular in recent years $[23,24]$.

In this paper, we first produced a divalent antibody, A33scFv-Fc, against GPA33 by fusing the humanized A33scFv to the Fc fragment of hIgG1 antibodies. Subsequently, we determined the immunoreactivity of CF750-, ${ }^{131} \mathrm{I}-$, and FITC-labeled A33scFv-Fc. Moreover, we evaluated CF570A33scFv-Fc by optically imaging mice with subcutaneous xenografts of human colon cancer. We also performed orthotopic tumor tissue dissections under the guidance of optical imaging with CF750-A33scFv-Fc. Finally, we analyzed the biodistribution of ${ }^{131} \mathrm{I}$-labeled $\mathrm{A} 33 \mathrm{scFv}-\mathrm{Fc}$ in a subcutaneous xenograft mouse model.

\section{Materials and Methods}

2.1. Construction of a pPIC9K-A33scFv-Fc Expression Plasmid. The genes encoding the variable heavy (VH) and light (VL) chains of intact antibody against A33 antigen were designed based on their amino acid sequences [20]. The single chain fragment of variable antibody against A33 antigen (A33scFv) was constructed in the format VH-(Gly4Ser)3-VL, with an additional $6 \mathrm{His}$ tag at the N-terminus. EcoRI and AvrII restriction sites were added at the $5^{\prime}$ and $3^{\prime}$ ends of the gene encoding $\mathrm{A} 33 \mathrm{scF}$, which was synthesized by Genscript Corporation (Nanjing, China). To construct the expression plasmid for A33scFv-Fc, an EcoRI/AvrII double-digested $\mathrm{A} 33 \mathrm{scFv}$ gene was ligated to a pPIC9K-hIgG1Fc plasmid containing a gene encoding an hIgG1 Fc fragment [25]. The sequence-verified plasmid was designated as pPIC9KA33scFv-Fc.

2.2. Expression and Purification of the A33scFv-Fc. To express the $\mathrm{A} 33 \mathrm{scFv}-\mathrm{Fc}$, we linearized the plasmid of pPIC9KA33scFv-Fc using SalI restriction enzymes, transforming them into Pichia pastoris GS115 competent cells by electroporation $(1.5 \mathrm{kV}, 200 \Omega$, and $25 \mu \mathrm{F})$ according to the instructions for the $P$. pastoris expression kit (Invitrogen, CA, USA). $\mathrm{His}^{+}$transformants were selected on histidinedeficient minimal dextrose (MD) plates. Subsequently, positive colonies were screened through PCR using the $\alpha$ factor primer $\left(5^{\prime}\right.$-TACTATTGCCAGCATTGCTGC- $\left.3^{\prime}\right)$ and the $3^{\prime}$ AOX1 primer $\left(5^{\prime}\right.$-GCAAATGGCATTCTGACATCC$\left.3^{\prime}\right)$. Moreover, the A33scFv-Fc-producing colonies were identified by western blot with an anti-His tag antibody. The expression and purification of the A33scFv-Fc were performed similarly, according to our previous work [26]. Briefly, cells derived from a single colony were inoculated into $25 \mathrm{~mL}$ buffered glycerol-complex medium (BMGY) and incubated at $28^{\circ} \mathrm{C}$ with shaking $(260 \mathrm{rpm})$ overnight. Then, the culture was transferred into $1 \mathrm{~L}$ fresh BMGY, and all of the cells were collected by centrifugation at room temperature (3,500 $\mathrm{g}$ for $5 \mathrm{~min})$ until the $A_{600 \mathrm{~nm}}$ of the culture reached approximately 6 , at which point it was resuspended in $100 \mathrm{~mL}$ of buffered methanol-complex medium (BMMY). Methanol (3\%) was added to the media daily to induce the expression of the $\mathrm{A} 33 \mathrm{scFv}-\mathrm{Fc}$ antibody. The culture supernatant was collected by centrifugation at $4^{\circ} \mathrm{C}(15,000 \mathrm{~g}$ for $15 \mathrm{~min})$ after an induction period, and the supernatant was dialyzed against binding buffer $(50 \mathrm{mM}$ Tris- $\mathrm{HCl}, 0.5 \mathrm{M} \mathrm{NaCl}$, and $10 \mathrm{mM}$ imidazole, $\mathrm{pH} 8.0$ ) at $4^{\circ} \mathrm{C}$ overnight. To improve the yield ofantibody, the expression conditions, including the initial $\mathrm{pH}$ values of the medium and the induction time, were optimized. The A33scFv-Fc was purified using Ni-NTA superflow (Qiagen, CA, USA). Subsequently, the purified antibody was dialyzed against phosphate-buffered saline (PBS, $8 \mathrm{~g} \mathrm{~L}^{-1} \mathrm{NaCl}, 0.2 \mathrm{gL}^{-1} \mathrm{KCl}, 3.49 \mathrm{gL}^{-1} \mathrm{Na}_{2} \mathrm{HPO}_{4} \cdot 12 \mathrm{H}_{2} \mathrm{O}$, and $0.2 \mathrm{gL}^{-1} \mathrm{KH}_{2} \mathrm{PO}_{4}$ ) at $4^{\circ} \mathrm{C}$ overnight. The protein concentration was measured using the Bradford method.

2.3. SDS-PAGE and Western Blot. Sodium dodecyl sulfate polyacrylamide gel electrophoresis (SDS-PAGE) and western blots were performed according to the descriptions in our previous work [27], with some modifications. Briefly, the proteins were separated on $10 \%$ gels and visualized by Coomassie Brilliant Blue. For western blots, the separated proteins were transferred onto polyvinylidene difluoride (PVDF) membranes (Bio-Rad, CA, USA) and incubated with a horseradish peroxidase- (HRP-) labeled antibody against the 6-His tag (Qiagen, CA, USA). Finally, the target proteins were visualized using a chemiluminescent substrate for HRP detection (Thermo, IL, USA).

\subsection{Labeling of $A 33 s c F v-F c$}

2.4.1. Labeling of $A 33 s c F v-F c$ with FITC. The labeling of the antibody with fluorescein isothiocyanate (FITC) was performed according to the EZ-Label FITC protein labeling kit (Pierce, CA, USA). Briefly, a 24-fold molar excess of FITC was added to the antibody $(1 \mathrm{mg} / \mathrm{mL}, \mathrm{pH} 8.5)$. After incubation at room temperature for $1 \mathrm{~h}$ in the darkness, the mixture was dialyzed against PBS with several buffer changes to remove the unconjugated FITC. 
2.4.2. Labeling of $A 33 s c F v-F c$ with $C F 750$. The labeling of the antibody with CF750 was performed according to our previous work [26]. Briefly, CF750 dye dissolved in dimethyl sulfoxide (DMSO) was added to the antibody $(1 \mathrm{mg} / \mathrm{mL}$, $\mathrm{pH}$ 8.3) at a $12: 1$ molar ratio of dye to antibody. After incubation at room temperature for $1 \mathrm{~h}$ in darkness, the mixture was dialyzed against PBS with several buffer changes to remove the excessive CF750 dye. The degree of labeling (DOL) was calculated according to the following formula: DOL $=\left(A_{755 \mathrm{~nm}} \times\right.$ molecular weight of antibody $\times$ dilution factor $) /(\varepsilon \times$ concentration of antibody $)$. The molar extinction coefficient $(\varepsilon)$ of CF750 is 250,000 .

2.4.3. Labeling of $A 33 s c F v-F c$ with Radionuclide ${ }^{131} I$. The labeling of the antibody with radionuclide ${ }^{131} \mathrm{I}$ was described in our previous work [26]. Briefly, the mixture containing $50 \mu \mathrm{g}$ antibody $(1 \mathrm{mg} / \mathrm{mL}), 7.4 \mathrm{MBq}$ of ${ }^{131}$ I-labeled sodium iodide (specific radioactivity $\geq 2.8 \mathrm{MBq} / \mu \mathrm{L}$ ), and $7.5 \mu \mathrm{g}$ of $\mathrm{N}$ bromosuccinimide $(1 \mathrm{mg} / \mathrm{mL})$ was incubated at room temperature with shaking for $5 \mathrm{~min}$. A PB-10 desalting column was used to remove the free sodium iodide, and thin layer chromatography (TLC) was used to determine the degree of labeling (DOL).

2.5. Cell Culture. The GPA33 antigen-positive LS174T, COLO205 cells and GPA33 antigen-negative SMMC7721, AGS cells were all purchased from the American Type Culture Collection (ATCC, VA, USA). Cells were cultured in medium (Dulbecco's Modified Eagle Medium for LS174T, RPMI-1640 for COLO205 and SMMC7721, and F-12K for AGS) containing $10 \%$ fetal bovine serum (FBS) at $37^{\circ} \mathrm{C}$ in a humidified atmosphere containing $5 \% \mathrm{CO}_{2}$.

\subsection{Immunoreactivity Assays}

2.6.1. Immunoreactivity Assay for FITC-A33scFv-Fc. To evaluate the immunoreactivity of FITC-labeled A33scFv-Fc, approximately $3 \times 10^{5}$ cells were incubated with $20 \mathrm{nM}$ FITClabeled antibody in $100 \mu \mathrm{L}$ PBS containing $0.5 \%$ calf serum at $37^{\circ} \mathrm{C}$ for $1 \mathrm{~h}$ in darkness, followed by analysis using a flow cytometer (Cytomics FC 500, Beckman Coulter, CA, USA). A FITC-labeled isotype antibody was utilized as a control in these assays.

2.6.2. Immunoreactivity Assay for CF750-A33scFv-Fc. The immunoreactivity of CF750-A33scFv-Fc was analyzed by dose-dependent cell binding assays. Briefly, approximately $3 \times 10^{5}$ LS174T cells were incubated with CF750-A33scFv-Fc antibody at different concentrations $(1,2,4,10$, and $20 \mathrm{nM})$ in $100 \mu \mathrm{L}$ PBS containing $0.5 \%$ calf serum at $37^{\circ} \mathrm{C}$ for $1 \mathrm{~h}$ in darkness. After two washes with PBS containing $0.5 \%$ calf serum, the cells were transferred onto a 96-well plate and scanned by the IVIS optical imaging system (Caliper Life Sciences, CA, USA). The fluorescence signal intensities of cells were analyzed.

2.6.3. Immunoreactivity Assay for ${ }^{131} I-A 33 s c F v$-Fc. Dosedependent cell binding assays were used to evaluate the immunoreactivity of the ${ }^{131}$ I-labeled antibody. Briefly, approximately $6 \times 10^{5}$ LS174T cells were incubated with the

${ }^{131} \mathrm{I}-\mathrm{A} 33 \mathrm{scFv}-\mathrm{Fc}$ antibody at different concentrations $(1,2.5$, $5,10,20,30$, and $60 \mathrm{nM}$ ) in $200 \mu \mathrm{L}$ PBS containing $0.5 \%$ calf serum at $37^{\circ} \mathrm{C}$ for $1 \mathrm{~h}$. After incubation, the cells were washed with PBS containing $0.5 \%$ calf serum twice, and the total radioactivity of the bound antibody was counted using a FJ-2008PS Gamma counter (Xian Nuclear Instrument Factory, Shanxi, China). The free ${ }^{131} \mathrm{I}+\mathrm{A} 33-\mathrm{scFv}-\mathrm{Fc}$ was used as a control.

2.7. Immunofluorescence Histochemistry. The tumor xenografts and liver tissues obtained from mice were immediately cut into frozen sections and stained with the FITC-labeled antibody in the dark at $4^{\circ} \mathrm{C}$ overnight. The cell nuclei were visualized using DAPI before being observed under fluorescence microscopy. A FITC-labeled isotype antibody was utilized as a negative control.

2.8. Optical Imaging of Mice Bearing Subcutaneous Tumor Xenografts. All of the protocols used in this experiment were approved by the University Animal Care and Use Committee. LS174T, COLO205, or SMMC7721 $\left(1 \times 10^{6}\right.$ cells/mouse) were subcutaneously implanted at the right flank of female BALB/C nu/nu mice (4 6 weeks). Tumor growth was monitored every day, and tumor volumes were calculated according to the following formula: width ${ }^{2} \times$ length $\times 0.5$. To monitor the tumor uptake of antibody, the mice $(n=3)$ bearing subcutaneous tumor xenografts (100 $200 \mathrm{~mm}^{3}$ ) were intravenously injected with CF750-A33scFv$\mathrm{Fc}(100 \mu \mathrm{g}$ in $100 \mu \mathrm{L})$ and were followed by kinetic scans using the IVIS optical imaging system at different time points after injection. To compare the uptake of CF750-A33scFv-Fc by the tumor and the other organs/tissues, the injected mice $(n=3)$ bearing LS174T xenografts were sacrificed, and the tumor, heart, liver, spleen, lung, kidney, stomach, colon, pancreas, small intestine, brain, and muscle were scanned at different time points after injection. The fluorescence signal intensities in the tumor and the other organs/tissues were analyzed. In the control group, the mice were injected with the same amount of unconjugated CF750 dye.

2.9. Optical Imaging of Mice with Orthotopic Tumor Transplantations. LS174T cells $\left(1 \times 10^{6}\right.$ cells/mouse $)$ were subcutaneously injected into female BALB/C nu/nu mice (4 6 weeks). When the tumor volume reached approximately $200 \sim 300 \mathrm{~mm}^{3}$, the tumor grafts were dissected and immediately cut into small granules $\left(\sim 1 \mathrm{~mm}^{3}\right)$, followed by the transplantation of these tissues into the colons of other nude mice. Once the tumor grafts were palpable, the mice $(n=$ 3) were injected with CF750-A33scFv-Fc $(100 \mu \mathrm{g}$ in $100 \mu \mathrm{L})$ followed by imaging using the IVIS optical imaging system at $5 \mathrm{~h}$ after injection. Subsequently, the mice were sacrificed, and laparotomy was performed. The orthotopic tumor tissues were identified and dissected under guidance by CF750A33scFv-Fc antibody-based optical imaging. 


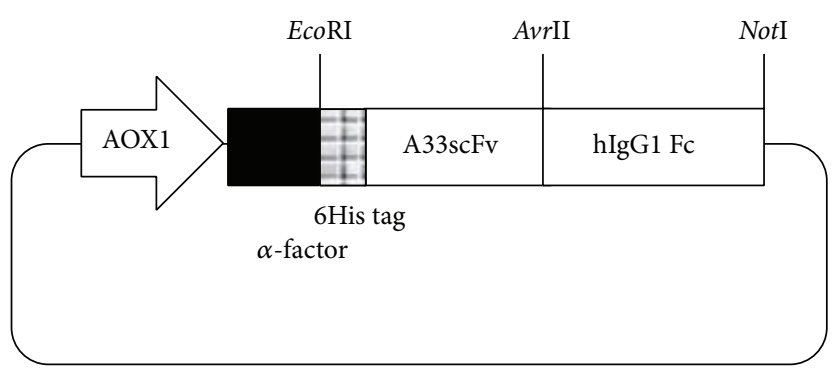

(a) (h)

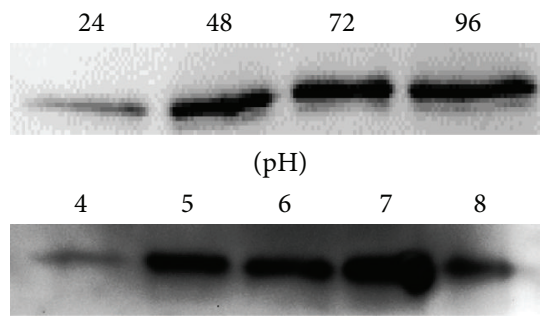

(b)

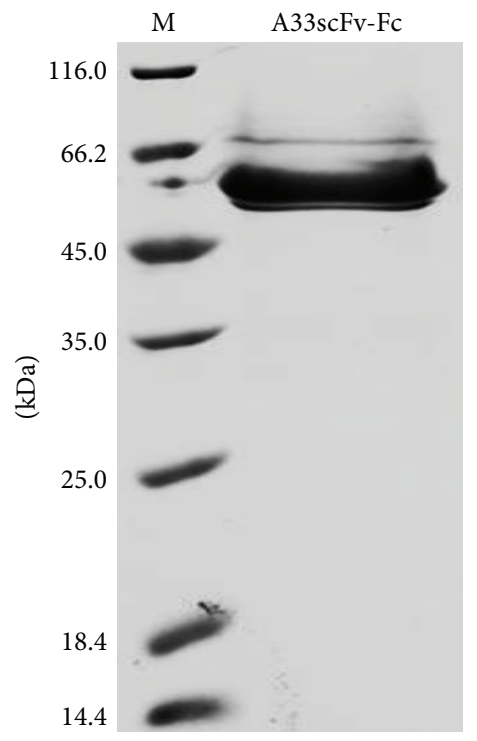

(c)

Figure 1: Expression and purification of A33scFv-Fc. (a) Schematic diagram of the pPIC9K-A33scFv-Fc expression vector. (b) Effects of the initial $\mathrm{pH}(4 \sim 8)$ of the inductive medium and inductive time $(24 \sim 96 \mathrm{~h})$ on the production of A33scFv-Fc. (c) SDS-PAGE analysis of purified A33scFv-Fc $(6 \mu \mathrm{g})$. M: protein markers.

2.10. Biodistribution of ${ }^{131} I-A 33 s c F v-F c$. To evaluate the biodistribution of ${ }^{131} \mathrm{I}-\mathrm{A} 33 \mathrm{scFv}-\mathrm{Fc}$, mice $(n=3)$ bearing subcutaneous LS174T tumor xenografts were intravenously injected with ${ }^{131} \mathrm{I}-\mathrm{A} 33 \mathrm{scFv}-\mathrm{Fc}(185 \mathrm{kBq} / \mathrm{g}$ body weight) and sacrificed at different time points. The tumor grafts and normal organs/tissues were taken out, weighed, and counted for radioactivity using the FJ-2008PS Gamma counter. The results are expressed as the percent injected dose per gram of tissue (\%ID/g).

\section{Results}

3.1. Production of $A 33 s c F v-F c$. To construct the pPIC9KA33scFv-Fc expression plasmid, an EcoRI/AvrII double digested A33scFv gene was ligated to the pPIC9K-hIgG1Fc vector. The schematic diagram of the pPIC9K-A33scFv-Fc expression plasmid is shown in Figure 1(a). To produce the A33scFv-Fc antibody, the pPIC9K-A33scFv-Fc plasmid was transformed into P. pastoris GS115 competent cells, followed by their identification with PCR and western blot (data not shown). To improve the production of $\mathrm{A} 33 \mathrm{scFv}-\mathrm{Fc}$, the initial
$\mathrm{pH}$ of inductive media and inductive time were optimized. As shown in Figure 1(b), A33scFv-Fc was expressed in media with an initial $\mathrm{pH}$ of $4.0 \sim 8.0$ and a peak at $\mathrm{pH}$ 7.0. Moreover, time-dependent analysis demonstrated that $\mathrm{A} 33 \mathrm{scFv}-\mathrm{Fc}$ accumulated in the medium throughout the induction time of $24 \sim 96 \mathrm{~h}$. Finally, the expression of $\mathrm{A} 33 \mathrm{scFv}-\mathrm{Fc}$ was induced for $96 \mathrm{~h}$ by daily additions of $3 \%$ methanol to a medium with an initial $\mathrm{pH}$ of 7.0. Figure 1(c) showed that A33scFvFc was recovered with approximately $90 \%$ purity from the supernatant using Ni-NTA affinity chromatography.

3.2. Immunoreactivity of $A 33 s c F v-F c$. The immunoreactivity of the FITC-, CF750-, and ${ }^{131}$ I-labelled A33scFv-Fc was examined using cell binding and immunofluorescence histochemistry. As shown in Figure 2(a), flow cytometry analysis demonstrated that the binding rates of FITC-A33scFv-Fc to GPA33-positive LS174T and COLO205 were $94 \%$ and $93.8 \%$, respectively. In contrast, the binding rates of FITC-A33scFvFc to GPA33-negative SMMC7721 and AGS cells were as low as $1.0 \%$ and $1.7 \%$. A33scFv-Fc has been indicated to be able to specifically bind GPA33-positive cells. Immunofluorescence 

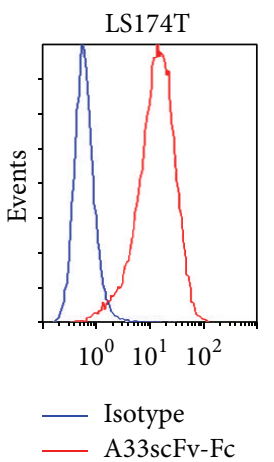

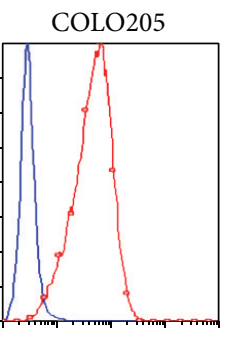

$\begin{array}{lll}10^{0} & 10^{1} & 10^{2}\end{array}$
SMMC7721

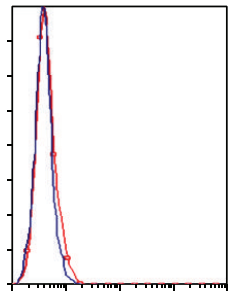

$\begin{array}{lll}10^{0} & 10^{1} & 10^{2}\end{array}$

- Isotype - A33scFv-Fc

(a)
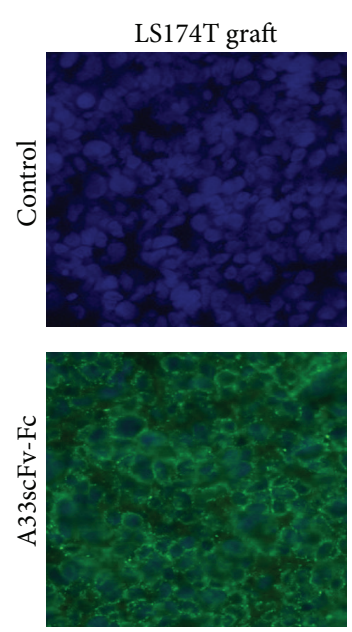

COLO205 graft
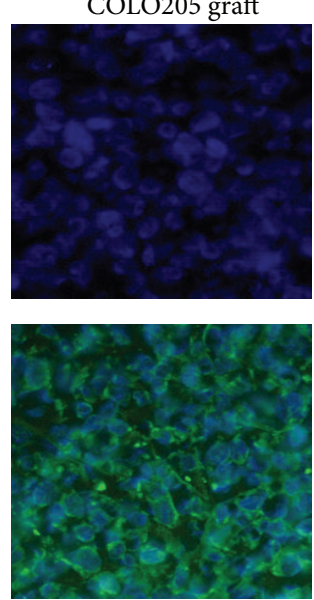

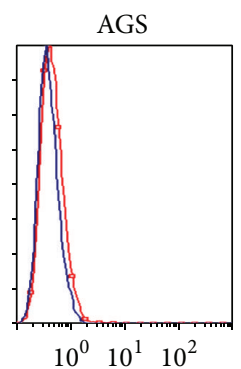

- Isotype

(a)

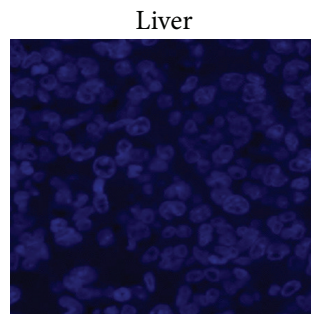

(b)

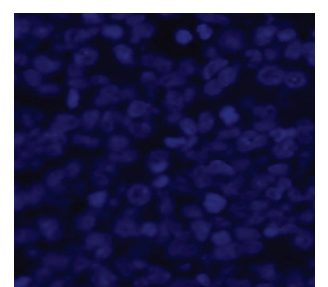

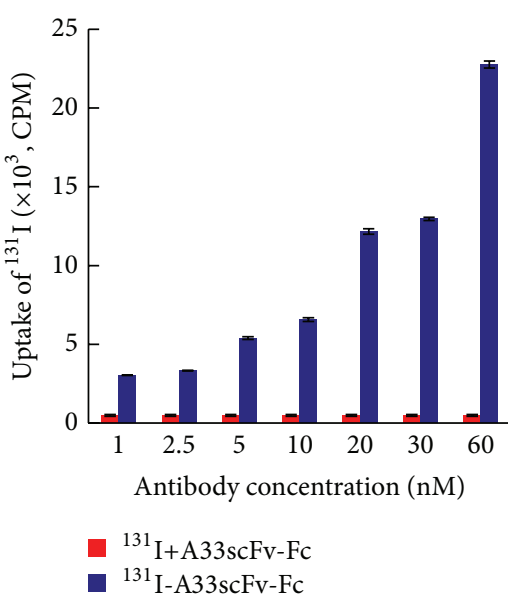

(c)
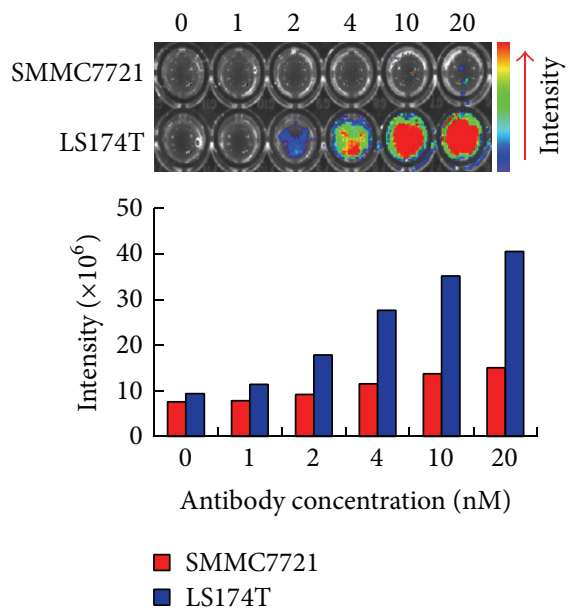

(d)

FIGURE 2: Immunoreactivity and specificity of A33scFv-Fc. (a) Cell binding assays of FITC-labeled A33scFv-Fc. GPA33-positive (LS174T, COLO205) and GPA33-negative (SMMC7721, AGS) cells were incubated with FITC-A33scFv-Fc, followed by flow cytometric analysis. (b) Immunofluorescence chemical assay for the tissue binding of FITC-A33scFv-Fc. LS174T, COLO205 tumor tissues, and liver tissues were stained with FITC-A33scFv-Fc and observed under a fluorescence microscope. The cell nuclei were stained with DAPI, and an isotype antibody was used as a negative control. (c) The cell binding of ${ }^{131} \mathrm{I}$-labeled A33scFv-Fc. LS174T cells were incubated with ${ }^{131} \mathrm{I}-\mathrm{A} 33 \mathrm{scFv}$ Fc at different concentrations (1 60 nM), followed by counting the radioactivity of cells using a gamma counter. The mixture containing the same amount of unconjugated ${ }^{131} \mathrm{I}$ and A33scFv-Fc was used as a control. (d) Cellular binding of CF750-labeled A33scFv-Fc. SMMC-7721 and COLO205 cells were incubated with the CF750-A33scFv-Fc at the indicated molar concentrations (0 20 nM) and followed by scanning with the IVIS optical imaging system. The fluorescence intensities of the cells were calculated and compared. 
(h)
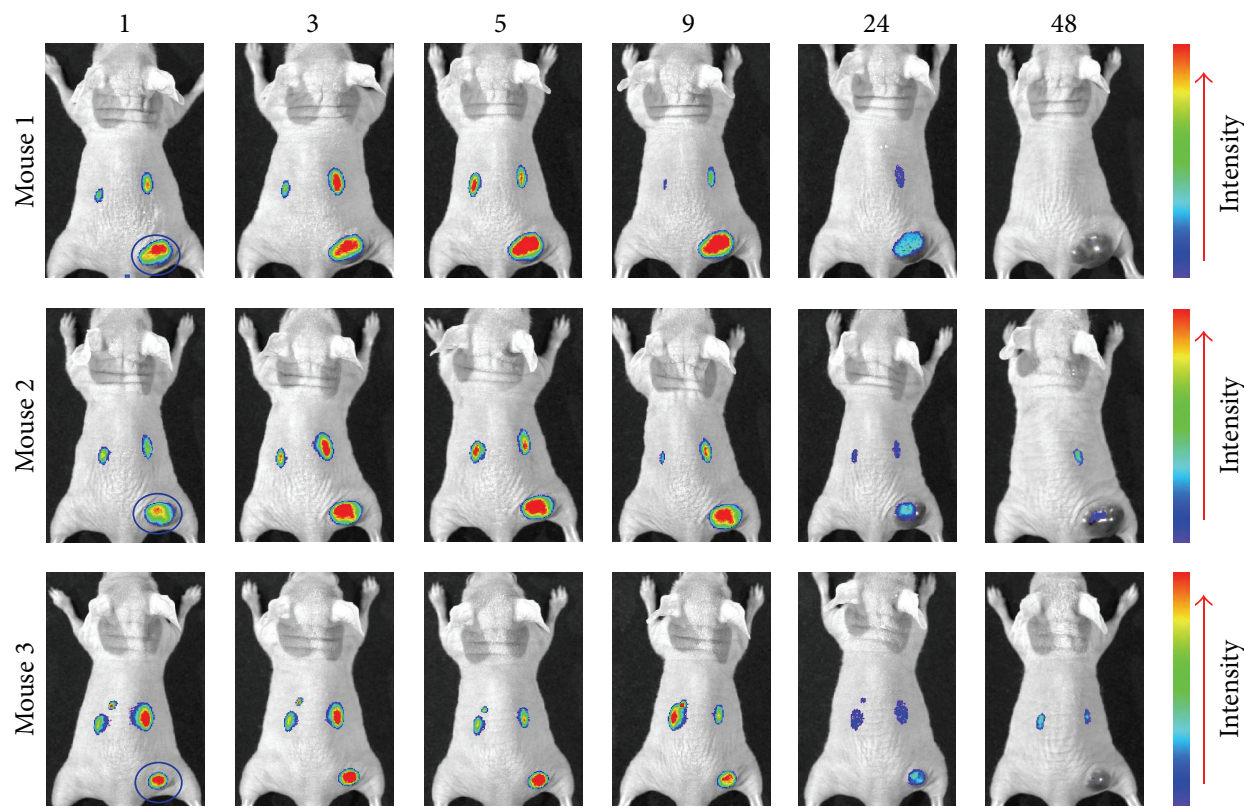

FIGURE 3: CF750-A33scFv-Fc-mediated optical imaging of mice bearing subcutaneous LS174T xenografts. Mice $(n=3)$ were intravenously injected with CF750-A33scFv-Fc $(100 \mu \mathrm{g})$ and scanned at 1, 3, 5, 9, 24, and $48 \mathrm{~h}$ after injection. The LS174T tumor xenografts are indicated by blue circle.

histochemistry further verified the specificity of A33scFvFc for the GPA33 antigen. As shown in Figure 2(b), FITCA33scFv-Fc bound GPA33-positive LS174T and COLO205 tumor tissues but not GPA33-negative liver tissue.

The immunoreactivity of ${ }^{131}$ I-labeled $\mathrm{A} 33 \mathrm{scFv}$-Fc was also determined by cell binding assays. LS174T cells were incubated with either ${ }^{131} \mathrm{I}-\mathrm{A} 33 \mathrm{scF}$-Fc or free ${ }^{131} \mathrm{I}+\mathrm{A} 33-\mathrm{scFv}$ $\mathrm{Fc}$, followed by counting the cell-bound radioactive signal. As shown in Figure 2(c), after incubation with ${ }^{131} \mathrm{I}-\mathrm{A} 33 \mathrm{scFv}$ $\mathrm{Fc}$, the radioactive signals of the cells increased along with the dose of the antibody. In contrast, dose-dependent binding was not observed in cells incubated with free ${ }^{131} \mathrm{I}+\mathrm{A} 33-\mathrm{scFv}$ Fc. These results demonstrate that ${ }^{131} \mathrm{I}$-labeled $\mathrm{A} 33 \mathrm{scFv}-\mathrm{Fc}$ is active in cell binding.

To examine the immunoreactivity of CF750-labeled antibody, LS174T cells and SMMC7721 cells were incubated with antibodies followed by being transferred into a 96-well plate and scanned using an IVIS optical imaging system. Figure 2(d) showed that the fluorescence intensity of the LS174T cells increased alongside the antibody. On the other hand, only low level of fluorescence intensity was detected in SMMC7721 cells incubated with the same amount of CF750$\mathrm{A} 33 \mathrm{scFv}-\mathrm{Fc}$. These data indicate that CF750-labeled A33scFvFc is able to specifically bind GPA33-positive LS174T cells.

3.3. Subcutaneous Tumor Targeting of CF750-A33scFv-Fc. To monitor the tumor uptake of the antibody, mice bearing subcutaneous LS174T xenografts were intravenously injected with CF750-A33scFv-Fc followed by kinetic scanning using an optical imaging system at $1,3,5,9,24$, and $48 \mathrm{~h}$ after injection. As shown in Figure 3, LS174T tumor grafts were visible at $1 \mathrm{~h}$ after injection, indicating the rapid tumor uptake of A33scFv-Fc. Moreover, A33scFv-Fc accumulated in the tumor grafts with time, peaking at $5 \mathrm{~h}$. High-contrast images of the subcutaneous LS174T tumor grafts were obtained at $3 \sim 9 \mathrm{~h}$ after injection. Although the tumor uptake of $\mathrm{A} 33 \mathrm{scFv}$ Fc was reduced by $24 \mathrm{~h}$, it was still detectable at $48 \mathrm{~h}$ after injection. To further compare the antibody uptake, mice injected with CF750-A33scFv-Fc were sacrificed, and the tumor grafts and other organs/tissues were scanned at 5, 9, 24 , and $48 \mathrm{~h}$ after injection. As shown in Figures 4(a) and 4(b), fluorescence signals were mainly detected in the kidney, liver, and tumor grafts at all time points. The uptake rates of A33scFv-Fc at each time point were as follows (from high to low): kidney $>$ liver $>$ tumor $>$ spleen $>$ lung $>$ heart $>$ stomach $>$ colon $>$ pancreas $>$ small intestine $>$ brain $>$ muscle. The uptake ratios at $5,9,24$, and $48 \mathrm{~h}$ were as follows: tumor-to-muscle: $19.8 \pm 5.3,15.5 \pm 2.5,17.4 \pm 5.6$, and $17.0 \pm$ 5.1; tumor-to-colon: $9.1 \pm 1.9,11.0 \pm 0.2,13.4 \pm 1.5$, and $7.8 \pm 3.5$; and tumor-to-small intestine: $19.1 \pm 7.3,21.8 \pm 4.8$, $24.6 \pm 5.5$, and $20.8 \pm 2.1$. These results demonstrated the high persistence of CF750-A33scFv-Fc in GPA33-positive LS174T tumor xenografts.

However, injecting the same amount of CF750-A33scFvFc did not allow the visualization of the subcutaneous GPA33negative SMMC 7721 tumor grafts (Figure 5(a)), indicating the high specificity of A33scFv-Fc. Surprisingly, we failed to obtain high-contrast images of mice with GPA33-positive COLO205 tumor grafts after they had been injected with the same amount of CF750-A33scFv-Fc (Figure 5(b)). To further compare the antibody uptakes by the COLO205 and LS174T xenografts, we inoculated COLO205 and LS174T 


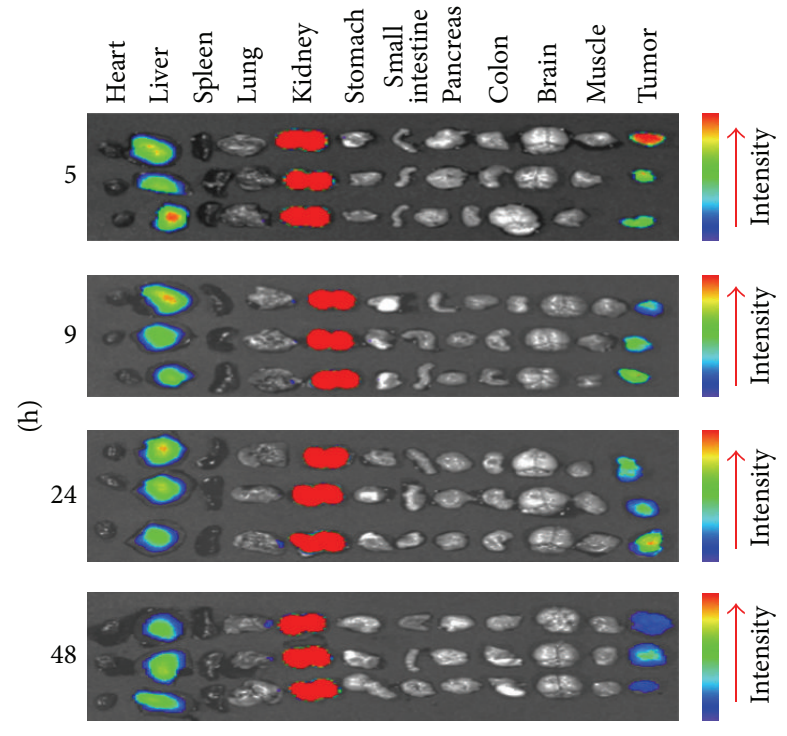

(a)

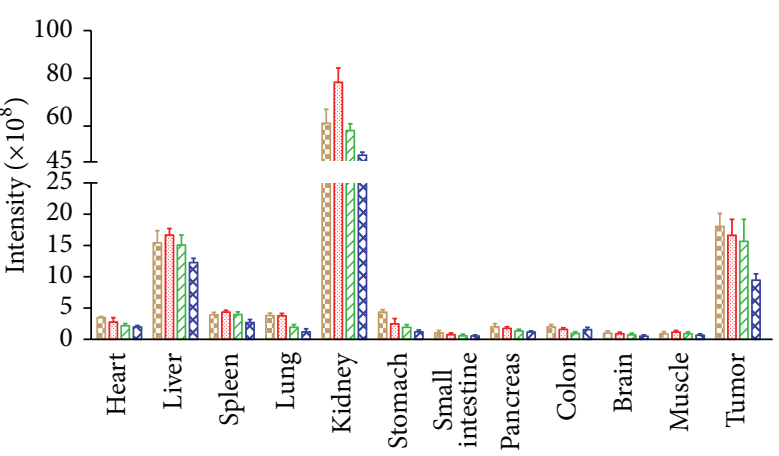

$5 \mathrm{~h}$ $9 \mathrm{~h}$
प्य $24 \mathrm{~h}$

区 $48 \mathrm{~h}$

(b)

FIGURE 4: Tissue distribution of CF750-A33scFv-Fc in mice bearing subcutaneous LS174T xenografts. (a) Optical imaging of the tumor grafts and organ tissues at different time points. Mice $(n=3)$ were intravenously injected with CF750-A33scFv-Fc $(100 \mu \mathrm{g})$ and sacrificed at 5 , 9, 24, and $48 \mathrm{~h}$ after injection. Tumor grafts and other normal organs/tissues were taken out and scanned using the optical imaging system. (b) The fluorescence intensities of CF750-A33scFv-Fc in the tumor grafts and the organs/tissues at the indicated time points.

(h)
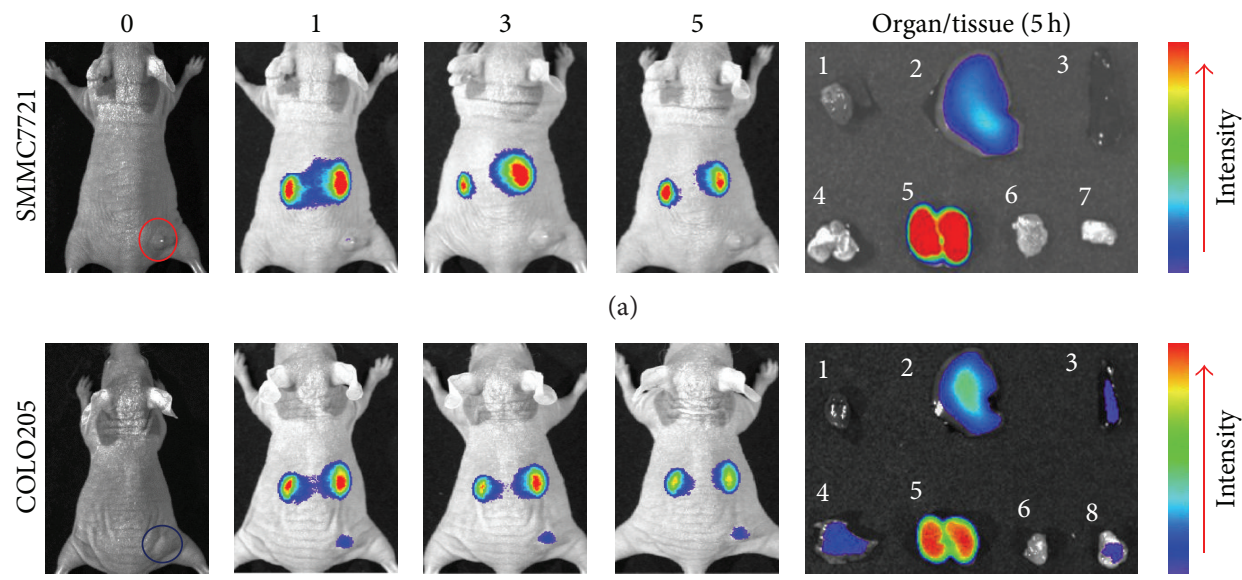

(a)
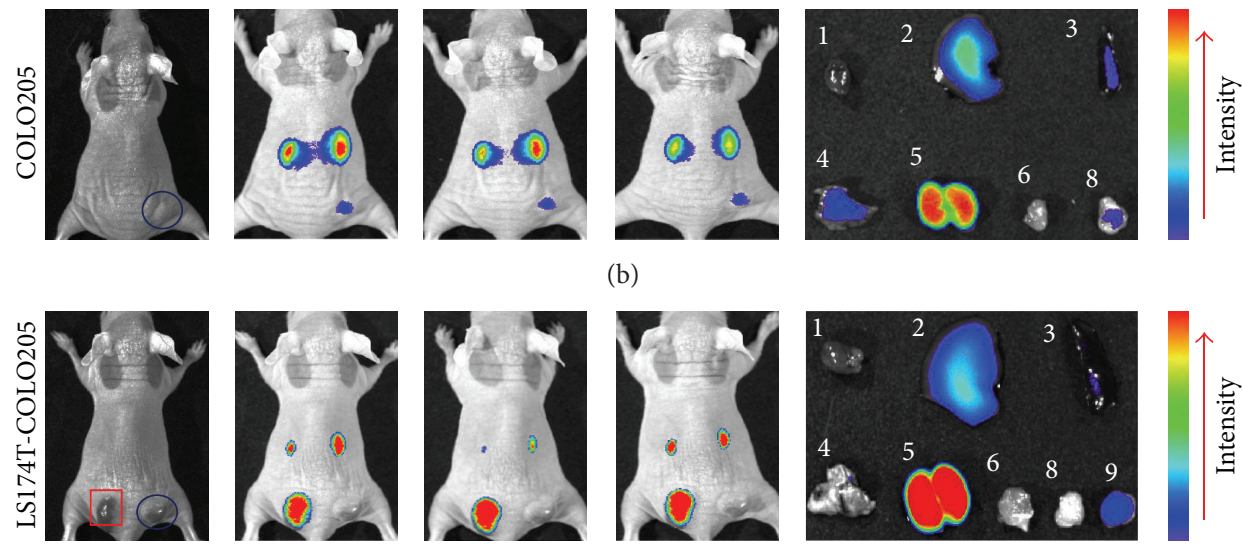

(b)
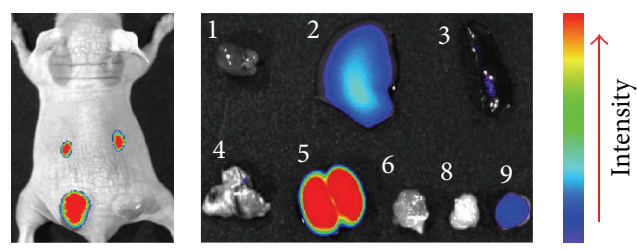

(c)

Figure 5: Optical imaging of mice bearing single SMMC7721 (a), COLO205 (b), or dual LS174T and COLO205 (c) xenografts. Mice $(n=3)$ bearing tumor grafts were intravenously injected with CF750-A33scFv-Fc $(100 \mu \mathrm{g})$ and scanned at 0, 1, 3, and $5 \mathrm{~h}$ after injection. SMMC7721, COLO205, and LS174T xenografts are indicated with red circle, blue circle, and red square, respectively. After the last scans (5 h), the mice were sacrificed, and the organs/tissues were removed and scanned. 1: heart, 2: liver, 3: spleen, 4: lung, 5: kidney, 6: muscle, 7: SMMC7721 tumor graft, 8: COLO205 tumor graft, and 9: LS174T tumor graft. 

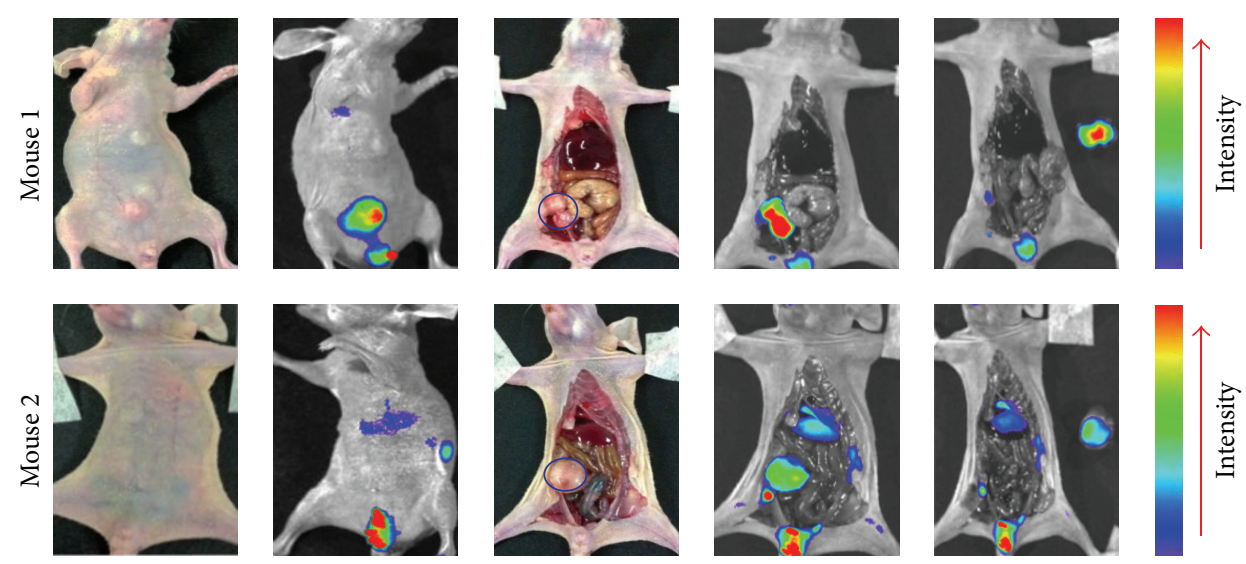

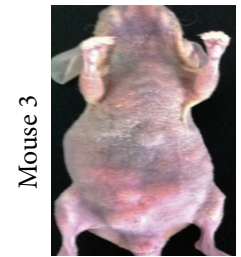

(a)

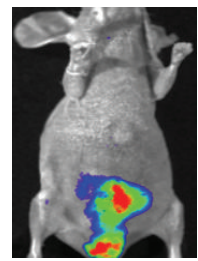

(b)

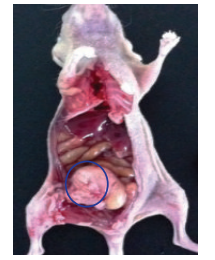

(c)

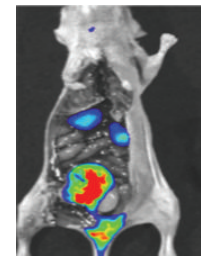

(d)

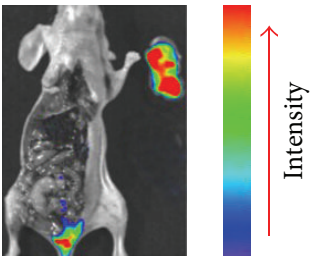

(e)

FIGURE 6: CF750-A33scFv-Fc-based optical imaging-directed orthotopic tumor tissue dissection. LS174T tumor tissues derived from xenografts were inoculated into colons of mice. Once the tumor tissues were palpable, the mice $(n=3)$ were injected with CF750-A33scFv-Fc $(100 \mu \mathrm{g})$ followed by scanning and tumor tissue dissection at $5 \mathrm{~h}$ after injection. Before laparotomy, the mice were first imaged using an optical imaging system with white light (a) and NIR filter settings (b). Next, laparotomy was performed, and the excrescent tumor tissues in the colon were identified by an optical imaging system ( $c$ and d). Finally, the orthotopic tumor tissues were removed under the guide of optical imaging (e). LS174T xenografts are indicated with blue circle.

cells in the same mice. As shown in Figure 5(c), after the injection of CF750-A33scFv-Fc into mice with dual tumor grafts, the fluorescence signal in the COLO205 xenograft was significantly lower than that in the LS174T xenograft. Because both COLO205 and LS174T cells were GPA33positive, these results suggest that $\mathrm{CF} 750-\mathrm{A} 33 \mathrm{scFv}-\mathrm{Fc}$ might not be effectively delivered into COLO205 tumor grafts.

3.4. Orthotopic Tumor Targeting of CF750-A33scFv-Fc. To evaluate the targeting of CF750-A33scFv-Fc in an orthotopic LS174T tumor transplantation mice model, the injected mice were first imaged using the optical imaging system from the abdomen without laparotomy. As shown in Figures 6(a) and 6(b), the bladders of three mice were visible under the optical imaging system at $5 \mathrm{~h}$ after injection, but tumor grafts were palpable in only two mice. Once the laparotomy was performed, excrescent tumor tissues in the colon were distinguished from normal tissues in three mice using CF750A33scFv-Fc (Figures 6(c) and 6(d)). Moreover, tumor tissues were accurately dissected under the guidance of an IVIS optical imaging system (Figure 6(e)). These results demonstrate that the CF750-A33scFv-Fc can target orthotopic LS174T tumor grafts.

3.5. Biodistribution Analysis of ${ }^{131} I-A 33 s c F v$-Fc. In a biodistribution assay, mice bearing subcutaneous LS174T tumor xenografts $\left(300 \sim 400 \mathrm{~mm}^{3}\right)$ were intravenously injected with
${ }^{131} \mathrm{I}-\mathrm{A} 33 \mathrm{scFv}-\mathrm{Fc}$. Subsequently, the mice were sacrificed at $0.08,0.5,2,5,8$, and $24 \mathrm{~h}$ after injection, followed by counting the radioactivity of tumor and organs/tissues. As shown in Table 1, the radioactivity of ${ }^{131} \mathrm{I}-\mathrm{A} 33 \mathrm{scFv}-\mathrm{Fc}$ in the tumor at 5 min was $4.12 \pm 0.76 \%$, indicating a rapid tumor uptake that increased with time and peaked at $5 \mathrm{~h}$ after injection, with an activity of $5.45 \pm 1.25 \%$. Thereafter, the tumor's radioactivity began to decrease but persisted at a high level at $24 \mathrm{~h}$ after injection. The radioactivity in the tumor was $2.03 \pm 0.51 \%$ at $24 \mathrm{~h}$ after injection, compared to $0.68 \pm 0.19 \%, 0.16 \pm 0.05 \%$, $0.47 \pm 0.16 \%$, and $0.38 \pm 0.11 \%$ in the blood, muscle, small intestine, and colon, respectively. As shown in Figure 7, the ratios of tumor-to-muscle were $4.3 \pm 0.3,4.7 \pm 0.4$, and $12.6 \pm 1$ at 5,8 , and $24 \mathrm{~h}$ after injection, respectively. The ratio of tumor-to-blood increased from $1.5 \pm 0.1$ at $5 \mathrm{~h}$ to $3.0 \pm 0.3$ at $24 \mathrm{~h}$. In addition, the ratios of tumor-to-small intestine and tumor-to-colon were as high as $4.4 \pm 0.7$ and $5.3 \pm 0.5$, respectively, at $24 \mathrm{~h}$ after injection. These results demonstrate that the ${ }^{131} \mathrm{I}-\mathrm{A} 33 \mathrm{scFv}-\mathrm{Fc}$ was able to specifically localize at the LS174T tumor.

\section{Discussion}

In this study, divalent $\mathrm{A} 33 \mathrm{scFv}-\mathrm{Fc}$ against GPA33 was prepared by fusing A33scFv to the Fc fragment of an hIgG1 antibody. In vitro cell binding assays demonstrated that 
TABLE 1: Biodistribution of ${ }^{131} \mathrm{I}-\mathrm{A} 33 \mathrm{scFv}-\mathrm{Fc}$ in nude mice bearing LS174T xenografts ( $n=3$ at each time point).

\begin{tabular}{|c|c|c|c|c|c|c|}
\hline Tissue & $0.08 \mathrm{~h}$ & $0.5 \mathrm{~h}$ & $2 \mathrm{~h}$ & $5 \mathrm{~h}$ & $8 \mathrm{~h}$ & $24 \mathrm{~h}$ \\
\hline Blood & $20.98 \pm 1.87$ & $10.92 \pm 2.43$ & $6.36 \pm 1.91$ & $2.86 \pm 0.14$ & $1.61 \pm 0.28$ & $0.68 \pm 0.19$ \\
\hline Heart & $10.36 \pm 2.74$ & $5.47 \pm 1.17$ & $3.16 \pm 0.90$ & $1.41 \pm 0.10$ & $0.81 \pm 0.14$ & $0.39 \pm 0.15$ \\
\hline Liver & $10.91 \pm 1.80$ & $9.52 \pm 1.10$ & $6.53 \pm 0.78$ & $3.28 \pm 0.21$ & $2.68 \pm 0.70$ & $2.12 \pm 0.88$ \\
\hline Spleen & $21.62 \pm 3.33$ & $16.63 \pm 2.96$ & $9.90 \pm 1.31$ & $5.03 \pm 0.48$ & $3.23 \pm 0.22$ & $2.72 \pm 1.28$ \\
\hline Lung & $35.16 \pm 10.71$ & $17.48 \pm 2.57$ & $8.56 \pm 2.49$ & $3.39 \pm 0.34$ & $1.66 \pm 0.18$ & $0.73 \pm 0.23$ \\
\hline Kidney & $30.35 \pm 2.40$ & $27.14 \pm 1.54$ & $20.51 \pm 1.46$ & $13.50 \pm 0.74$ & $11.48 \pm 0.96$ & $7.61 \pm 2.19$ \\
\hline Stomach & $11.59 \pm 3.28$ & $16.07 \pm 2.32$ & $29.63 \pm 9.02$ & $11.93 \pm 0.64$ & $4.61 \pm 1.18$ & $1.28 \pm 0.43$ \\
\hline Small intestine & $8.82 \pm 1.72$ & $6.71 \pm 1.03$ & $4.36 \pm 2.52$ & $2.86 \pm 0.96$ & $2.00 \pm 1.44$ & $0.47 \pm 0.16$ \\
\hline Pancreas & $9.96 \pm 1.17$ & $7.25 \pm 0.60$ & $9.37 \pm 3.18$ & $4.38 \pm 0.44$ & $1.50 \pm 0.32$ & $0.29 \pm 0.05$ \\
\hline Colon & $6.39 \pm 1.67$ & $3.79 \pm 0.87$ & $5.47 \pm 1.37$ & $2.07 \pm 0.28$ & $0.95 \pm 0.19$ & $0.38 \pm 0.11$ \\
\hline Brain & $1.45 \pm 0.02$ & $0.85 \pm 0.09$ & $0.81 \pm 0.20$ & $0.27 \pm 0.02$ & $0.15 \pm 0.01$ & $0.03 \pm 0.01$ \\
\hline Muscle & $4.00 \pm 0.26$ & $2.47 \pm 0.12$ & $2.57 \pm 0.41$ & $0.98 \pm 0.08$ & $0.62 \pm 0.12$ & $0.16 \pm 0.05$ \\
\hline Tumor & $4.28 \pm 0.37$ & $4.99 \pm 0.06$ & $5.45 \pm 1.25$ & $4.21 \pm 0.29$ & $2.90 \pm 0.37$ & $2.03 \pm 0.51$ \\
\hline
\end{tabular}

$\% \mathrm{ID} / \mathrm{g}$ : the percent of injected dose per gram tissue.

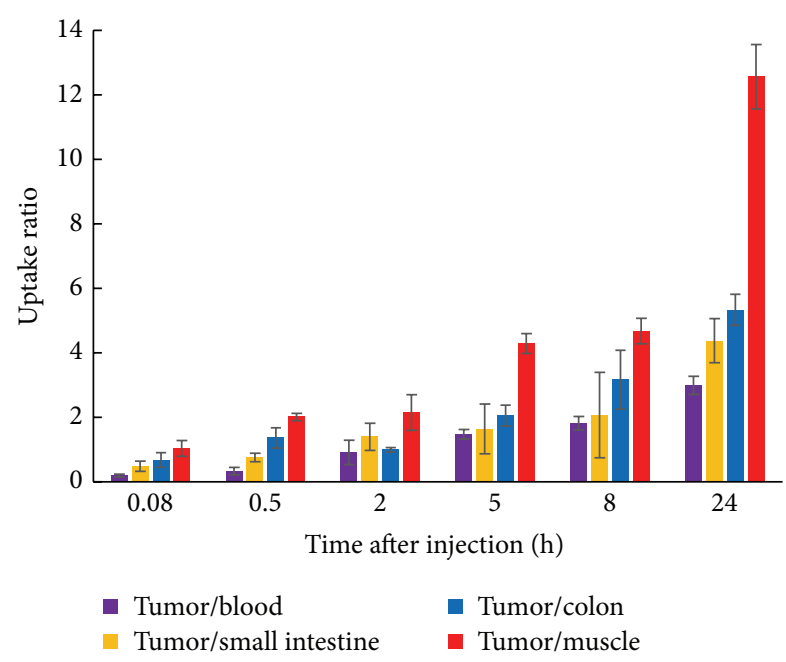

FIGURE 7: The ${ }^{131} \mathrm{I}-\mathrm{A} 33 \mathrm{scFv}-\mathrm{Fc}$ uptake ratio of tumor to normal tissues at different time points. Mice $(n=3)$ bearing subcutaneous LS174T tumor xenografts were intravenously injected with ${ }^{131} \mathrm{I}-$ A33scFv-Fc ( $185 \mathrm{kBq} / \mathrm{g}$ body weight) and then sacrificed at 0.08 , $0.5,2,5,8$, and $24 \mathrm{~h}$ after injection, respectively. The radioactivity of the organ/tissue was counted, and the ratios of tumor-to-blood, tumor-to-small intestine, tumor-to-colon, and tumor-to-muscle were calculated.

the A33scFv-Fc produced by $P$. pastoris can bind GPA33positive but not GPA-negative tumor cells. In mice bearing subcutaneous xenografts, CF750-labeled A33scFv-Fc was accumulated rapidly in GPA33-positive LS174T xenografts but not in GPA33-negative SMMC7721 xenografts. Moreover, orthotopic LS174T tumor tissues were dissected successfully under the guidance of an optical imaging system using CF750-labeled A33scFv-Fc as an indicator. Biodistribution analysis revealed a rapid tumor uptake and a high level persistence of $\mathrm{A} 33 \mathrm{scFv}-\mathrm{Fc}$ in the xenografts. These results suggest that $\mathrm{A} 33 \mathrm{scFv}-\mathrm{Fc}$ could be developed as a useful imaging agent for colorectal cancer.

Due to their high specificity and affinity for antigens, antibody-based imaging agents are ideal for tumor diagnostics. Taking into account the slow tumor targeting and serum persistence of large intact antibodies, approaches for building small antibodies, including scFv-Fc, minibody, diabody, and scFv, have been constructed in the past decades $[28,29]$. Building $\mathrm{scFv}$ was the first step toward engineering a small antibody. In fact, we began by preparing $\mathrm{A} 33 \mathrm{scFv}$ and evaluating its potential as an imaging agent for GPA33-positive colorectal cancer. As shown in supplementary Figure 1(a) (in Supplementary Material available online at http://dx.doi.org/10.1155/2015/505183), A33scFv can also bind GAP33-positive LS174T cells. However, the affinity of $\mathrm{A} 33 \mathrm{scFv}-\mathrm{Fc}$ for LS174T cells was much higher than that of A33scFv. For example, the mean fluorescence intensities (MFI) of cells incubated with 10 and $20 \mathrm{nM}$ FITC-A33scFvFc were 4.5- and 4.2-fold of that of $\mathrm{A} 33 \mathrm{scFv}$, respectively (supplementary Figure 1(b)). Moreover, the injection of CF750-A33scFv-Fc produced high-contrast images of mice bearing LS174T xenografts (Figure 3), but the injection of the same amount of CF750-A33scFv gave images with low contrast (supplementary Figure 2(a)). Further tissue scanning demonstrated that the tumor uptake of CF750A33scFv-Fc (Figure 4(a)) was obviously higher than that of CF750-A33scFv (supplementary Figure 2(b)). The fluorescence intensity of CF750-A33scFv-Fc in tumor grafts at $9 \mathrm{~h}$ (Figure 4(b)) was approximately 3 5 times higher than that of CF750-A33scFv at $7 \mathrm{~h}$ (supplementary Figure 2(c)). In addition, the CF750-A33scFv-Fc uptake ratios of tumor-tomuscle, tumor-to-colon, and tumor-to-small intestine were $15.5 \pm 2.5,11.0 \pm 0.2$, and $21.8 \pm 4.8$, respectively, compared to $7.5 \pm 1.9,3.2 \pm 1.5$, and $5.4 \pm 2.1$ among CF750$\mathrm{A} 33 \mathrm{scFv}$. These results suggest that divalent CF750-A33scFvFc is more properly used than monovalent CF750-A33scFv as an imaging agent for colorectal cancer. Nevertheless, because an Fc fragment might introduce such side effects as 
antibody-dependent cell-mediated cytotoxicity (ADCC) and complement-dependent cytotoxicity (CDC) [30], it might be better to produce a GPA33-recognizing diabody or minibody without an Fc fragment as an imaging agent in the future.

It is known that NIR fluorescence probes have low autofluorescence and low absorbance in normal tissue within the NIR region (700 900 $\mathrm{nm}$ ), which can potentially increase the sensitivity and specificity of a cancer diagnosis [31]. Consequently, NIR fluorescence probe-labeled antibodies without radiation injury have become attractive as novel tools for tumor imaging. Usually, mice bearing subcutaneous tumor xenografts are used for the preclinical biological evaluation of tumor imaging agents. In our experiment, we first evaluated CF750-A33scFv-Fc in mice bearing subcutaneous LS174T tumor grafts. Because an injection of CF750-A33scFvFc produced high-contrast images in subcutaneous tumorbearing mice (Figure 3), we further investigated whether the orthotopic tumor grafts could be dissected under the guidance of CF750-A33scFv-Fc-based optical imaging. As shown in Figure 6, after the laparotomy of the mice injected with CF750-A33scFv-Fc, optical imaging demonstrated that a fluorescence signal was predominantly detectable in tumor tissues and the liver. In particular, the excrescent tumor tissue was distinguished from that of the normal colon using the optical imaging system. Finally, the tumor tissue was accurately dissected under the guidance of the optical imaging system. These results suggest that CF750-A33scFvFc-based imaging agent might facilitate the surgical removal of colorectal cancer while keeping both patients and surgeons free from radiation.

However, unlike the LS174T tumor grafts, the COLO205 tumor grafts in mice injected with the same amount of CF750-A33scFv-Fc were visualized with low contrast (Figure 5(b)), suggesting a difference between COLO205 and LS174T tumor grafts in uptake of CF750-A33scFv-Fc. To reduce the bias caused by individual differences between mice and batch variations of CF750-A33scFv-Fc, we further used mice bearing both COLO205 and LS174T tumor grafts to evaluate the uptake of CF750-A33scFv-Fc. Scanning the mice and the tissues revealed that the uptake of CF750-A33scFvFc by the COLO205 tumor graft was significantly less than that by the LS174T tumor graft (Figure 5(c)). Flow cytometric analysis with FITC-A33scFv-Fc demonstrated that GPA33 was expressed on the surfaces of COLO205 and LS174T cells (Figure 2(a)). Further, there was no obvious difference in either cell line in MFI after incubation with the same amount of FITC-A33scFv-Fc (data not shown). Immunofluorescence histochemistry revealed that even though membrane GPA33 was expressed in both COLO205 and LS174T tumor grafts at a similar level (Figure 2(b)), the LS174T xenografts were hypervascular [32]. The expression of vascular endothelial growth factor (VEGF) in LS174T cells was much higher than that in COLO205, suggesting a difference between the xenografts of LS174T and COLO205 in vascularization [33, 34]. In fact, we found blood vessel-rich areas in LS174T but not in COLO205 tumor xenografts. These different vascularizations may have led to the differences between COLO205 and LS174T tumor xenografts in their delivery of A33scFvFc. Consequently, CF750-A33scFv-Fc might be limited in utility for imaging blood vessel-rich colorectal cancer. Still, the injection of a small tumor-homing peptide produced clear images of COLO205 tumor xenografts (data not shown), suggesting that the tissue-penetrating ability of A33scFv-Fc is poor. A33scFv-based diabody or minibody with reduced molecular weight but retained affinity might possess a higher tissue-penetrating ability. Moreover, the tissue penetration of A33scFv-Fc might also be improved by fusion with tissuepenetrating peptides [35].

\section{Conflict of Interests}

The authors declare that there is no conflict of interests regarding the publication of this paper.

\section{Authors' Contribution}

Danfeng Wei and Qing Fan contributed equally to this work.

\section{Acknowledgments}

This work was supported by the National Natural Science Fund of China (81273419) and the National Key Clinical Program.

\section{References}

[1] A. Jemal, M. M. Center, C. DeSantis, and E. M. Ward, "Global patterns of cancer incidence and mortality rates and trends," Cancer Epidemiology Biomarkers \& Prevention, vol. 19, no. 8, pp. 1893-1907, 2010.

[2] M. M. Center, A. Jemal, R. A. Smith, and E. Ward, "Worldwide variations in colorectal cancer," CA Cancer Journal for Clinicians, vol. 59, no. 6, pp. 366-378, 2009.

[3] M. M. Center, A. Jemal, and E. Ward, "International trends in colorectal cancer incidence rates," Cancer Epidemiology, Biomarkers \& Prevention, vol. 18, no. 6, pp. 1688-1694, 2009.

[4] B. Vogelstein, E. R. Fearon, S. R. Hamilton et al., "Genetic alterations during colorectal-tumor development," The New England Journal of Medicine, vol. 319, no. 9, pp. 525-532, 1988.

[5] J. D. Potter, "Colorectal cancer: molecules and populations," Journal of the National Cancer Institute, vol. 91, no. 11, pp. 916932, 1999.

[6] R. A. Weinberg, "Oncogenes, antioncogenes, and the molecular bases of multistep carcinogenesis," Cancer Research, vol. 49, no. 14, pp. 3713-3721, 1989.

[7] A. G. Zauber, I. Lansdorp-Vogelaar, A. B. Knudsen, J. Wilschut, M. Van Ballegooijen, and K. M. Kuntz, "Evaluating test strategies for colorectal cancer screening: a decision analysis for the US Preventive Services Task Force," Annals of Internal Medicine, vol. 149, no. 9, pp. 659-669, 2008.

[8] J. S. Mandel, J. H. Bond, T. R. Church et al., "Reducing mortality from colorectal cancer by screening for fecal occult blood," The New England Journal of Medicine, vol. 328, no. 19, pp. 1365-1371, 1993.

[9] A. D. Muller and A. Sonnenberg, "Prevention of colorectal cancer by flexible endoscopy and polypectomy: a case-control study of 32702 veterans," Annals of Internal Medicine, vol. 123, no. 12, pp. 904-910, 1995. 
[10] S. Winawer, R. Fletcher, D. Rex et al., "Colorectal cancer screening and surveillance: clinical guidelines and rationaleupdate based on new evidence," Gastroenterology, vol. 124, no. 2, pp. 544-560, 2003.

[11] U. Iqbal, H. Albaghdadi, Y. Luo et al., "Molecular imaging of glioblastoma multiforme using anti-insulin-like growth factorbinding protein-7 single-domain antibodies," British Journal of Cancer, vol. 103, no. 10, pp. 1606-1616, 2010.

[12] V. Sarangthem, E. A. Cho, S. M. Bae et al., "Construction and application of elastin like polypeptide containing IL-4 receptor targeting peptide," PLoS ONE, vol. 8, no. 12, Article ID e81891, 2013.

[13] S. Kaur, G. Venktaraman, M. Jain, S. Senapati, P. K. Garg, and S. K. Batra, "Recent trends in antibody-based oncologic imaging," Cancer Letters, vol. 315, no. 2, pp. 97-111, 2012.

[14] P. Garin-Chesa, J. Sakamoto, S. Welt, F. X. Real, W. J. Rettig, and L. J. Old, "Organ-specific expression of the colon cancer antigen A33, a cell surface target for antibody-based therapy," International Journal of Oncology, vol. 9, no. 3, pp. 465-471, 1996.

[15] J. K. Heath, S. J. White, C. N. Johnstone et al., "The human A33 antigen is a transmembrane glycoprotein and a novel member of the immunoglobulin superfamily," Proceedings of the National Academy of Sciences of the United States of America, vol. 94, no. 2, pp. 469-474, 1997.

[16] S. Welt, C. R. Divgi, F. X. Real et al., "Quantitative analysis of antibody localization in human metastatic colon cancer: a phase I study of monoclonal antibody A33," Journal of Clinical Oncology, vol. 8, no. 11, pp. 1894-1906, 1990.

[17] D. J. King, P. Antoniw, R. J. Owens et al., "Preparation and preclinical evaluation of humanised A33 immunoconjugates for radioimmunotherapy," British Journal of Cancer, vol. 72, no. 6, pp. 1364-1372, 1995.

[18] F. T. Lee, C. Hall, A. Rigopoulos et al., "Immuno-PET of human colon xenograft-bearing BALB/c nude mice using ${ }^{124} \mathrm{I}-$ CDR-grafted humanized A33 monoclonal antibody," Journal of Nuclear Medicine, vol. 42, no. 5, pp. 764-769, 2001.

[19] J. A. Carrasquillo, N. Pandit-Taskar, J. A. O'Donoghue et al., "124 I-huA33 antibody PET of colorectal cancer," Journal of Nuclear Medicine, vol. 52, no. 8, pp. 1173-1180, 2011.

[20] C. Rader, G. Ritter, S. Nathan et al., "The rabbit antibody repertoire as a novel source for the generation of therapeutic human antibodies," The Journal of Biological Chemistry, vol. 275, no. 18, pp. 13668-13676, 2000.

[21] L. M. Damasceno, I. Pla, H.-J. Chang et al., "An optimized fermentation process for high-level production of a single-chain Fv antibody fragment in Pichia pastoris," Protein Expression and Purification, vol. 37, no. 1, pp. 18-26, 2004.

[22] L. M. Damasceno, K. A. Anderson, G. Ritter, J. M. Cregg, L. J. Old, and C. A. Batt, "Cooverexpression of chaperones for enhanced secretion of a single-chain antibody fragment in Pichia pastoris," Applied Microbiology and Biotechnology, vol. 74, no. 2, pp. 381-389, 2007.

[23] P. Zou, S. Xu, S. P. Povoski et al., "Near-infrared fluorescence labeled anti-TAG-72 monoclonal antibodies for tumor imaging in colorectal cancer xenograft mice," Molecular Pharmaceutics, vol. 6, no. 2, pp. 428-440, 2009.

[24] D. Li, S. Liu, R. Liu et al., "EphB4-targeted imaging with antibody h131, h131-F $\left(\mathrm{ab}^{\prime}\right)_{2}$ and h131-Fab," Molecular Pharmaceutics, vol. 10, no. 12, pp. 4527-4533, 2013.

[25] L. Wan, S. Zhu, J. Zhu et al., "Production and characterization of a CD25-specific scFv-Fc antibody secreted from Pichia pastoris," Applied Microbiology and Biotechnology, vol. 97, no. 9, pp. 3855-3863, 2013.

[26] Q. Fan, H. Cai, H. Yang et al., "Biological evaluation of ${ }^{131} \mathrm{I}-$ and CF750-labeled Dmab(scFv)-Fc antibodies for xenograft imaging of CD25-positive tumors," BioMed Research International, vol. 2014, Article ID 459676, 11 pages, 2014.

[27] L. Wan, H. Cai, H. Yang et al., "High-level expression of a functional humanized single-chain variable fragment antibody against CD25 in Pichia pastoris," Applied Microbiology and Biotechnology, vol. 81, no. 1, pp. 33-41, 2008.

[28] A. M. Wu, "Engineered antibodies for molecular imaging of cancer," Methods, vol. 65, no. 1, pp. 139-147, 2014.

[29] P. Holliger and P. J. Hudson, "Engineered antibody fragments and the rise of single domains," Nature Biotechnology, vol. 23, no. 9, pp. 1126-1136, 2005.

[30] E. Kaneko and R. Niwa, "Optimizing therapeutic antibody function: progress with fc domain engineering," BioDrugs, vol. 25, no. 1, pp. 1-11, 2011.

[31] E. M. Sevick-Muraca, "Translation of near-infrared fluorescence imaging technologies: emerging clinical applications," Annual Review of Medicine, vol. 63, pp. 217-231, 2012.

[32] T. Fujii, M. Tachibana, D. K. Dhar et al., "Combination therapy with paclitaxel and thalidomide inhibits angiogenesis and growth of human colon cancer xenograft in mice," Anticancer Research, vol. 23, no. 3, pp. 2405-2411, 2003.

[33] D. T. Dang, S. Y. Chun, K. Burkitt et al., "Hypoxia-inducible factor-1 target genes as indicators of tumor vessel response to vascular endothelial growth factor inhibition," Cancer Research, vol. 68, no. 6, pp. 1872-1880, 2008.

[34] R. S. Warren, H. Yuan, M. R. Matli, N. A. Gillett, and N. Ferrara, "Regulation by vascular endothelial growth factor of human colon cancer tumorigenesis in a mouse model of experimental liver metastasis," The Journal of Clinical Investigation, vol. 95, no. 4, pp. 1789-1797, 1995.

[35] T.-H. Shin, E.-S. Sung, Y.-J. Kim et al., "Enhancement of the tumor penetration of monoclonal antibody by fusion of a neuropilin-targeting peptide improves the antitumor efficacy," Molecular Cancer Therapeutics, vol. 13, no. 3, pp. 651-661, 2014. 


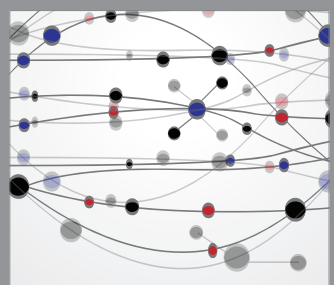

The Scientific World Journal
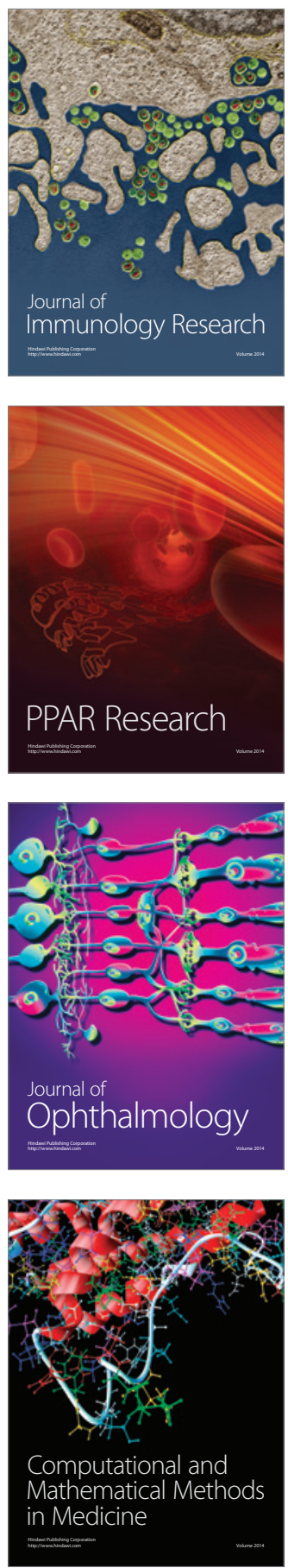

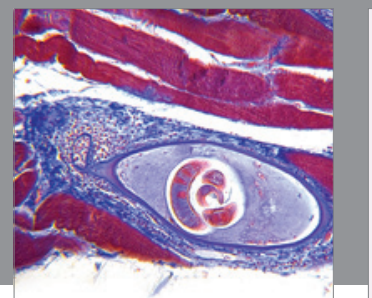

Gastroenterology

Research and Practice
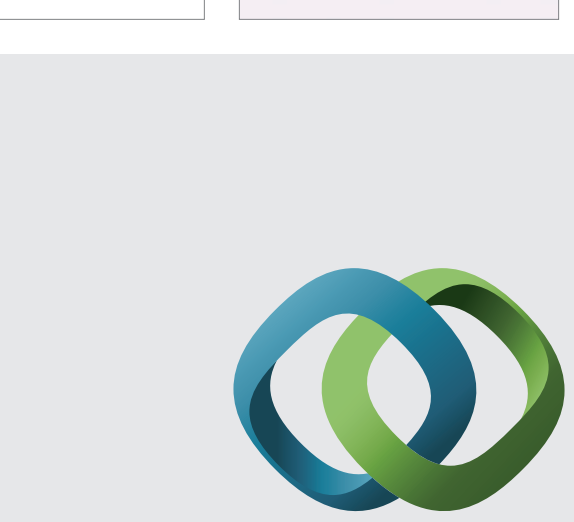

\section{Hindawi}

Submit your manuscripts at

http://www.hindawi.com
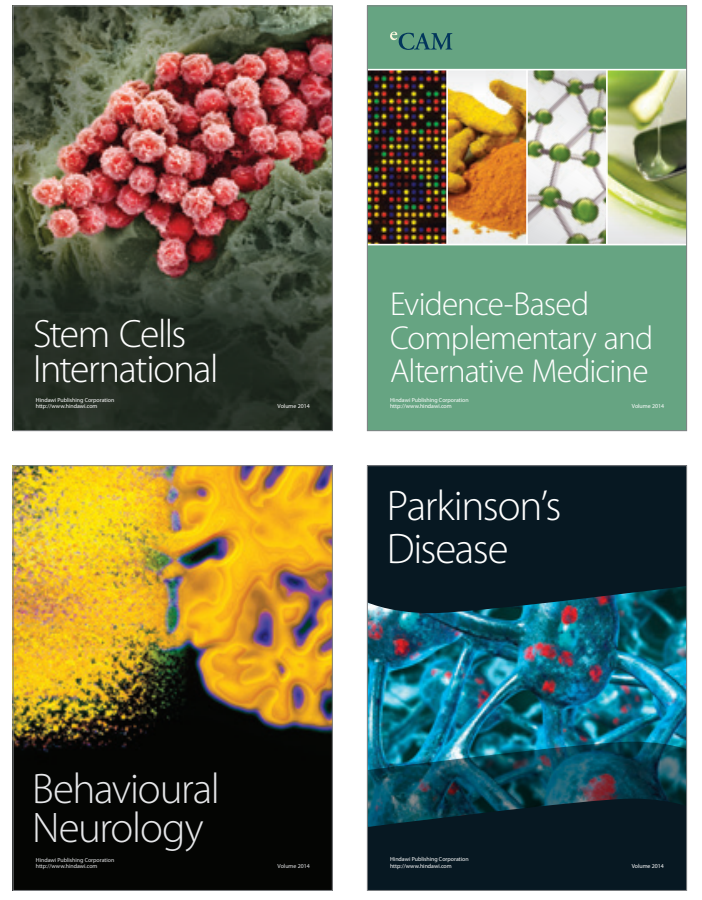
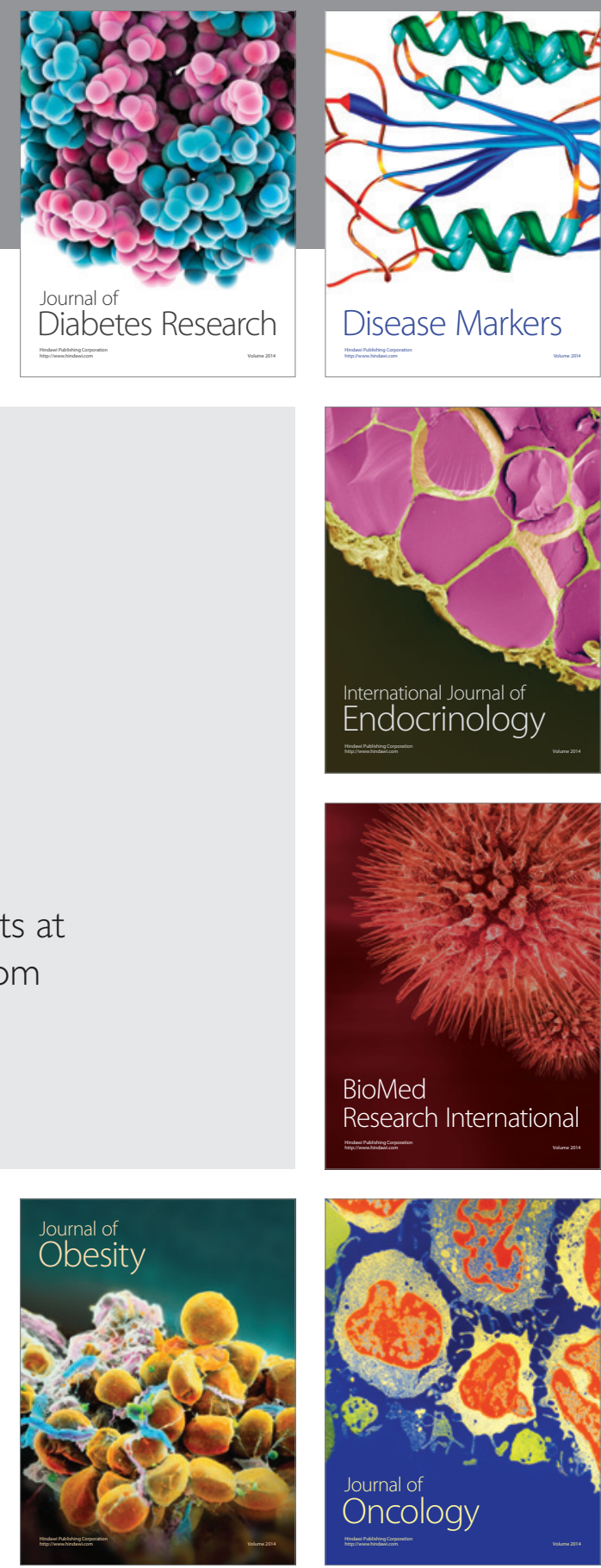

Disease Markers
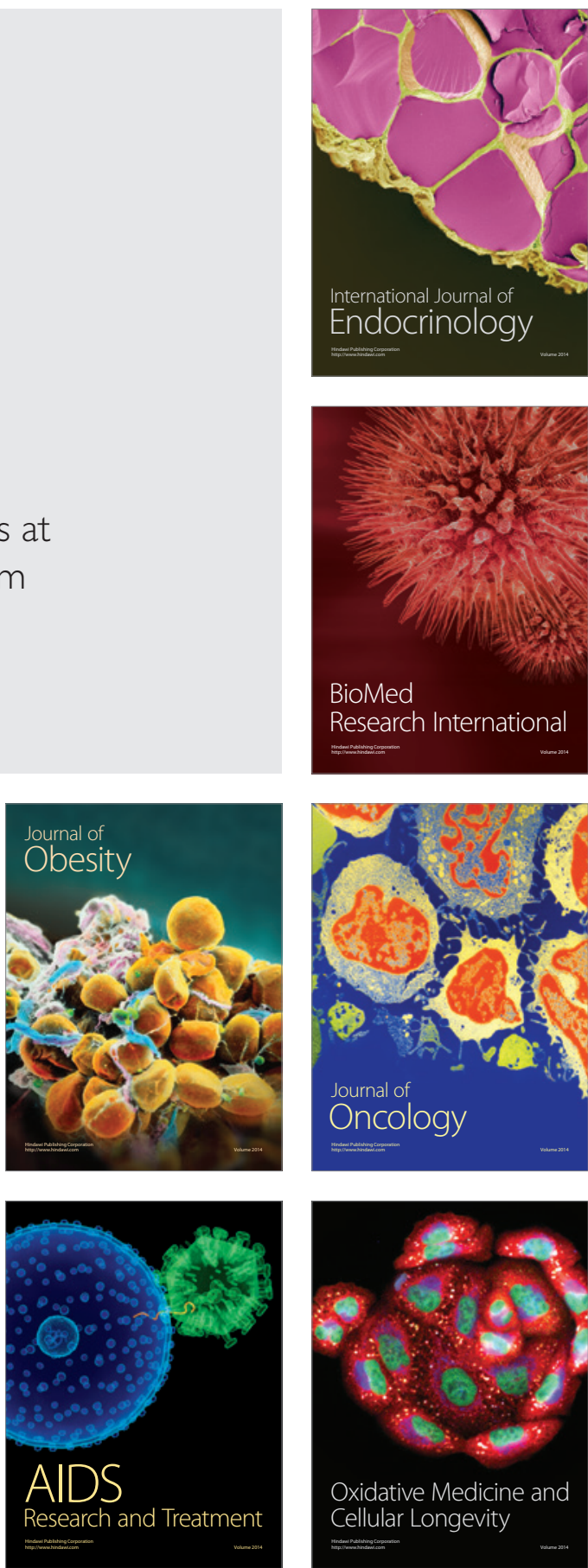